DOI 10.18551/rjoas.2021-11.19

\title{
FACTORS AFFECTING AGRIBUSINESS COMPETITIVENESS OF PINEAPPLE (ANANAS COMOSUS L. MERR) IN PEMALANG REGENCY, INDONESIA
}

\author{
Budiastuti Nyevi Ria*, Roessali Wiludjeng, Setiawan Bambang Mulyatno \\ Faculty of Animal and Agricultural Sciences, Diponegoro University, Semarang, Indonesia \\ *E-mail: dhe.nyep@gmail.com
}

\begin{abstract}
This study were aims to (1) analyze the potential production and profitability of pineapple farming in Pemalang Regency, (2) analyze the factors affecting pineapple production, (3) analyze comparative advantage, competitive advantage and the impact of government policies of pineapple agribusiness system in Pemalang Regency. The location was conducted in Belik District, Pemalang Regency. Survey method was used in this research using questionaire. Research area was chosen purposively in Belik District based on it has highest Pineapple production in Pemalang regency. Sensus method was employed for choosing among 50 respondents. Active members of farmers' group in Belik District were choosen for respondents. Data were analysis to identify potential production, profitability, and competitiveness analysis. The data analysis techniques used were profit analysis, production function analysis, competitiveness analysis. Result of analysis shows that pineapple farm in Pemalang regency had mediate production amounted to $0,51 \mathrm{~kg} / \mathrm{leave} / \mathrm{year}$. It was equal production of $13.221,45 \mathrm{~kg} / 4.708 \mathrm{~m}^{2}$ with $\mathrm{R} / \mathrm{C}$ ratio of 3,41 and probability value of $5,40 \% /$ month. The result was higher than interest rates of $0,46 \% /$ month. It can be said than pineapple farm in Pemalang regency was feasible. Meanwhile, production factors (namely: farm size, number of farm labour, seed, ethrel, fertilizer, chemical fertilizer, experience in farming system dan harvesting period) had significant effect toward pineapple farm simultaneously in a year. Moreover, In farm size, number of farm labour and harvesting period had significant effect toward pineapple farm. In addition, fertilizer and chemical fertilizer, ethrel and experience in farming system had not significantly effect toward pineapple farm. Pineapple farm had strong competitive ability as indicated by PCR and DRCR value of 0,26 and 0,15 , respectively. NPCI value of 0,52 shows that it had impact on farmer' tradability. NPCO value of 0,56 show that there was lack of impact on government policy toward farmer' output. Moreover, government policy of input and output on pineapple farm had not been achieved positive effect toward income of pineapple farmers in Pemalang Regency.
\end{abstract}

\section{KEY WORDS}

Agribusiness, farming, policy, pineapple.

Agricultural development does not only emphasize food commodities but also for developing fruit commodities. Apart from having high economic value, fruits are also able to fulfill the nutritional adequacy required by humans. National fruit production in 2017 was mango 2,567 thousand tons, pineapple production 1,902 thousand tons, mangosteen production 121 thousand tons, snake fruit production 1,153 thousand tons, orange production 2,050 thousand tons and other fruit production 12,828 thousand tons. In addition, other vegetable production is 7,845 thousand tons, medicinal plant production is 640 thousand tons, flower and cut leaf production is 803,824 thousand stalks, potted plants and landscapes production is 49,436 thousand trees, sown flower production is 40 thousand tons (Directorate General of Horticulture, 2017).

In Central Java, the total production of fruit plants in 2018 is $82,606,702$ tons. Three commodities that provide the largest contribution to fruit production in Central Java Province include Pemalang Regency: pineapple $(593,692)$, banana $(273,658)$ and mango $(254,183)$; Purbalingga Regency: pineapple $(255,522)$, banana $(124,608)$ and mango $(5,587)$. Pineapple (Ananas comosus L.Merr.) is one of the leading horticultural commodities in Indonesia. 
Based on data from BPS-Statistic Indonesia in 2018, national pineapple production reached $1,049,138$ tons. When compared with the national pineapple production in 2017 which amounted to 859,381 tons, there was an increase in production of 189,757 tons (Pemalang Regency Agriculture and Forestry Service, 2018). Pineapple is one of the tropical fruits thatis in great demand both domestically and abroad.

The development of agricultural products, especially pineapple, can function in: (a) building food security, which is related to aspects of product supply, aspects of income and affordability and aspects of independence; (b) sources of foreign exchange earnings, particularly in relation to comparative advantage and competitive advantage in international markets; (c) creation of new business fields and growth, especially in relation to opportunities for developing new business activities and exploiting the domestic market; and (d) developing new products related to various global issues and future development trends (BPS-Statistic of Central Java, 2018).

Pineapple production in Central Java Province in 2017 was 859,381 tons with the highest production contribution in pineapple production centers, namely Pemalang Regency at 593,692 tons or $70 \%$ of the total pineapple production in Central Java Province, while 31 other Regencies / Cities contributed less than 1 (one) percent (Novitasari, 2015). Therefore, the Pemalang Regency Government issued a Regent Regulation Number 48 of 2018 concerning the Plan for the Development of a Rural Area for Pineapple Agribusiness Centers in Belik District, Pemalang Regency in 2019-2023, in order to support this design it is very important to conduct research on the analysis of the income / profit level of pineapple analysis of production factors so that Pemalang pineapple products have high competitiveness (JDIH SetdaPemalang Regency, 2018).

Belik District, Pemalang Regency, which is located at the foot of Mount Slamet, is a pineapple producing center, which originally came from Bogor, in the 1950s the honey pineapple was brought to Pemalang to be cultivated. In the Pemalang area, the name honey pineapple is given to Jakarta middlemen because it tastes like honey. Pemalang honey pineapple has smaller physical characteristics with the largest size of 2 adult fists, but the taste is no less delicious. Even some honey pineapple farmers in the Belik area claim that the honey pineapple from Belik tastes sweeter than the pineapple honey from Subang. Besides being sweet like honey, Pemalang honey pineapple is also not too rough on the tongue. Pemalang honey pineapple is sweeter because the water content is not too much. The land conditions on the slopes of the mountains also affect the water content in pineapples. Because they are superior in terms of taste, pineapple farmers in the Pemalang area have experienced a flood of demand (Astoko, 2014).

The production is expected to increase the competitiveness of pineapple agribusiness development in Pemalang Regency. This development is in accordance with local conditions so that the quantity and quality of pineapple production in Pemalang Regency is recognized nationally and internationally. This study were aims to (1) analyze the potential production and profitability of pineapple farming in Pemalang Regency, (2) analyze the factors affecting pineapple production, (3) analyze comparative advantage, competitive advantage and the impact of government policies of pineapple agribusiness system in Pemalang Regency.

\section{METHODS OF RESEARCH}

The research location is in Belik Disrict, Pemalang Regency because it is the largest pineapple production center in Central Java and as a district that is a top priority in developing pineapple commodity production centers in Central Java Province. Pemalang Regency was chosen as the main priority for pineapple commodity development in Central Java and refers to considerations of economic value, comparative advantage, agro-climate suitability, and agribusiness approach of the agricultural commodity.

The independent variables in this study were land area, labor, seeds, fruit regulators (ethrel), manure, chemical fertilizer, length of farming and harvest frequency. Meanwhile, the dependent variable is pineapple production. 
Survey method was used in this research using questionaire. Research area was chosen purposively in Belik District based on it has highest Pineapple production in Pemalang regency. Sensus method was employed for choosing among 50 respondents. Active members of farmers' group in Delik District were choosen for respondents. Data were analysis to identify potential production, profitability, and competitiveness analysis.

This study uses two data, namely, primary data and secondary data. Primary data were obtained by direct interviews, observation methods or structured observation from pineapple farmers based on questionnaires that had been obtained, while the data were obtained from offices or agencies related to this research.

Data analysis carried out in this study includes quantitative analysis which is intended to process and organize data, and to find results that can be read and interpreted. Quantitative analysis is carried out by certain methods.

Data analysis in this research is descriptive quantitative method, namely by making a table from the data obtained and then calculated based on the cost of production, revenue, income $\mathrm{R} / \mathrm{C}$ ratio and profitability as well as doing a one sample t-test difference test.

Income $(\Pi)$ is calculated using a formula referring to Suratiyah (2015):

$$
\Pi=\mathrm{TR}-\mathrm{TC} \text { where TR }=\mathrm{P} \cdot \mathrm{Q} \text { and } \mathrm{TC}=\mathrm{TFC}+\mathrm{TVC}
$$

Where TR is Total Revenue (IDR); TC is Total Cost (IDR); TFC is Total Fixed Cost (IDR); TVC is Total Variable Cost (IDR); $P$ is the selling price of pineapples (IDR) and $Q$ is the amount of pineapples sold $(\mathrm{kg})$. The revenue and cost ratio $(\mathrm{R} / \mathrm{C}$ ratio) refers to (Maulidah, 2012) with the R / C formula as TR / TC. The calculation of profitability refers to Ambarsari et al. (2014) is the ratio of income (П) to production costs (TC) multiplied by $100 \%$.

The one sampe t-test difference test in this study was used to compare the average $\mathrm{R} / \mathrm{C}$ ratio of pineapple farming with the $\mathrm{R} / \mathrm{C}$ ratio in general, which is 1 . The one-sample ttest difference is carried out with the aim of testing whether a certain value (comparison) there is a difference in real or not with the average sample to be tested. The test results show significance $(\alpha)<0.05$ then $\mathrm{Ho}$ is rejected and if $\alpha>0.05$ then $\mathrm{HO}$ is accepted. Ho's decision is accepted with a significance value $>0.05$, which means that there is no difference between the comparators and the sample average, while Ha's decision is accepted if the significance value is $<0.05$, which means that there is a difference between the comparators (Suryani and Hendriyadi, 2015).

The analysis used to determine the factors that influence pineapple production uses the Cobb Douglas function. The Cobb Douglas production function formula is transformed into a linear multiple regression natural logarithm equation according to Soekartawi (2003):

$$
L n Y=\ln a+b_{1} \ln X_{1}+b_{2} \ln X_{2}+b_{3} \ln X_{3}+b_{4} \ln X_{4}+b_{5} \ln X_{5}+b_{6} \ln X_{6}+b_{7} \ln X_{7}+b_{8} \ln X_{8}+e
$$

Where:

Y: Pineapple production per-period (4 years) $(\mathrm{Kg})$;

a: Regression Constata;

$b_{12,3,4,5,6,7}$ : Coefficient Regression for variable 1, 2 , 3, 4, 5, 6, 7, 8;

$\mathrm{X}_{1}$ : Pineapple Plantation land area $\left(\mathrm{m}^{2}\right)$;

$\mathrm{X}_{2:}$ Sum of labor per year (HOK);

$\mathrm{X}_{3}$ : sum of seeds used in 1 period;

$\mathrm{X}_{4}$ : Amount of fruits stimulant used in 1 (one) planting period (package);

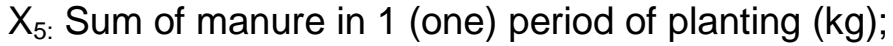

$\mathrm{X}_{6}$ : Sum of chemical fertilizer used in 1 (one) period of planting $(\mathrm{kg})$;

$\mathrm{X}_{7}$ : Duration of farming (score);

$\mathrm{X}_{8}$ : harvest frequency in 1 (satu) year (score);

e: error term.

According to Soekartawi (2003) there are 3 (three) alternatives to the Return to Scale condition, namely: 
1. Decreasing return to scale, if $\beta 1+\beta 2<1$, in this condition it can be interpreted that the proportion of additional production factors exceeds the proportion of additional production. For example, if the use of production factors is increased by $25 \%$, then the production will be increased by $15 \%$;

2. Constant return to scale, if $\beta 1+\beta 2=1$, in this situation the addition of production factors will be proportional to the increase in production obtained. For example, if the factor of production is added by $25 \%$, then the production will increase by $25 \%$;

3. Increasing return to scale, if $\beta 1+\beta 2>1$, this means that the proportion of additional production factors will result in additional production of a larger proportion. If the factor of production is added by $10 \%$, then the production will increase by $20 \%$. variable.

Ho: $\alpha<0.05 \diamond$ variable $n$ (independent) has a significant effect on the dependent variable.

Ho: $\alpha>0.05 \diamond$ variable $\mathrm{n}$ (independent) has no significant effect on the dependent

The $\mathrm{F}$ test is a test that uses the simultaneous regression of the dependent variables to determine together whether the independent variables have a significant effect on the dependent variable (Ghozali, 2011).

$\mathrm{Ho}: \mathrm{b}=0 \rightarrow$ if the regression coefficient $=0$, then all independent variables do not have a simultaneous effect on income.

$\mathrm{Ha}: \mathrm{b} \neq 0 \rightarrow$ if the regression coefficient $\neq 0$, then all independent variables have a simultaneous effect on income or at least one variable has an effect.

The $\mathrm{T}$ test used to determine the effect of all independent variables individually (partially) on the dependent variable (Santoso, 2010). The way to find out the acceptance of the hypothesis in the T test is to compare the value of T calculated in SPSS with the T table. The Ho hypothesis is accepted if the significance value is $>0.05$, which explains that there is a partial effect of the research variables (Suyono, 2018).

Ho: $b=0 \rightarrow$ if the regression coefficient $=0$, then each independent variable has no partial effect on income.

Ha: $b \neq 0 \rightarrow$ if the regression coefficient $\neq 0$, then each independent variable has $a$ partial effect on income.

The competitiveness analysis used is the Policy Analysis Matrix (PAM). Is an analysis that can identify two calculations, namely profit (Financial Analysis and Economic Analysis) and analysis of the impact of government policies that affect input and output on commodities. The calculation of the PAM model is carried out through the PAM matrix shown in the table below (Pasaribu, 2012)

Table 1 - Perhitungan Model PAM

\begin{tabular}{llllll}
\hline \multirow{2}{*}{ No. } & \multirow{2}{*}{ Items } & Revenue Output & Cost & & \\
\cline { 3 - 5 } & & Input Tradeable & Input Nontreadable & Profit \\
\hline 1 & Private cost & A & B & C & D \\
2 & Social Cost & E & F & G & H \\
3 & Policy Impact & I & J & K & L \\
\hline
\end{tabular}

Source: Pasaribu (2012).

Note:

Financial Profit (D): $A-(B+C)$;

Financial Profit $(\mathrm{H})$ : $\mathrm{E}-(\mathrm{F}+\mathrm{G})$;

Transfer output (OT) (I): A-E;

Transfer input tradeable (IT) (J): B-F;

Transfer input non-tredeable (FT) (K): C-G;

Netto Transfer (NT) (L): I-(K+J);

Private Cost Ratio (PCR): C/(A-B);

Ratio BSD (DRC): G/(E-F);

Nominal output protection coefficient (NPCO): $A / E$;

Nominal input protection coefficient (PNPCI): B/F;

Effective protection coefficient (EPC): $(A-B) /(E-F)$;

Profit coefficient (PC): D/H;

Subsidy ratio producer (SRP): L/E. 
According to Mulyadi (2012) the pesticide used in farming, Atabron which is a domestic production, whose raw materials consist of foreign (importable) and domestic (untradeable) components. In pineapple agribusiness, it does not use pesticides but uses etrel, so the social etrel price is calculated using the formula:

$$
\begin{gathered}
P_{x}=P_{\text {importable }}+P_{\text {domestik }} \\
P_{x}=a \cdot P_{\text {privat }} \cdot \frac{S E R}{O E R} \\
P_{\text {domestik }}=(1-a) \cdot P_{x}
\end{gathered}
$$

Where: $P_{x:}$ - etrel social price $(R p / p a c k) ; P_{\text {domestic }}$ - untradeable component price (Rp/pack); $P_{\text {importable: }}$ - import component price (Rp/pack); $P_{\text {private: }}$ - material etrel private price (Rp/pack); a - importable component section (\%); (1-a) - domestic component section (\%).

Whether there is a comparative advantage of pineapple commodity, the criteria for domestic resource cost ratio (DRCR) are used. DRCR is a comparative advantage indicator that shows the amount of domestic resources that can be saved to generate one unit of foreign exchange. The system is said to have a comparative advantage if the DRCR is $\leq 1$, and vice versa if the DRCR $>1$ does not have a comparative advantage. To determine the comparative advantage, private cost ratio (PCR) criteria are used. PCR is an indicator of private profitability that shows the ability of a commodity system to pay for domestic resource costs and remain competitive. If PCR $\leq 1$, it means the commodity system studied has a competitive advantage and if PCR> 1 means the commodity system does not have a competitive advantage. Government policy on output is explained by output transfer (OT) and nominal protection coefficient on output (NPCO). The output transfer is the difference between the revenue at the private price and the revenue at the social price. If the OT value> 0 indicates a transfer from consumers (the public) to consumers, if the OT value $<0$, then there is no transfer from consumers to producers. NPCO is an indicator that shows the level of government protection against domestic output. If the NPCO value $>1$ indicates a policy that protects domestic output and vice versa if NPCO $<1$ indicates no policy that protects domestic output or a policy that is disincentive in nature.

Government policy towards input is explained by the value of input transfer, nominal protection coefficient on input and transfer factor. Value IT>0 indicates a transfer from producer farmers to trade able input producers, if IT $<0$ indicates no transfer from producer farmers to trade able input producers. NPCl is an indicator that shows the level of government protection against domesticagricultural input prices. The policy is protective towards domestic input if the NPCl value is $<1$ or in other words there is a subsidy policy for trade able inputs, if the NPCl value is $>0$ then there is no subsidy policy for trade able inputs. Transfer factor is a value that shows the difference between the private price and the social price received by producers for payment of non-traded production factors. FT value $>0$ indicates that there is a transfer from producer farmers to non-tradable input producers, and vice versa Government policy on output and input is explained by the Effective protection coefficient (EPC), which is an indicator that shows the simultaneous level of protection against tradable output and input. The policy is protective if the EPC value is $>1$. The greater the EPC value, the higher the government protection for domestic agricultural commodities. Net transfer (NT) is the difference between the net profit actually received by producers and the net social benefits. The NPT value $>0$ indicates additional producer surplus caused by government policies applied to input and output, and vice versa. The profitability coefficient (PC) is the profit coefficient, which is the ratio between the net profit actually received by producers and the net social profit. If $\mathrm{PC}>1$ indicates that overall government policies provide incentives to producers. And the subsidy ratio to producer (SRP) is an indicator that shows the proportion of revenue at the social price needed if subsidies or taxes are used as a substitute for government policies. A positive SRP value indicates a positive impact from government policy (Pasaribu, 2012). 


\section{RESULTS AND DISCUSSION}

Respondents of this study were pineapple farmers in Belik District, Pemalang Regency. The identity of the respondent can be explained in several characteristics, namely the age of the respondent, the level of education, farming experience, main occupation and the amount of land ownership.

Table 2 - The identity of Respondents in Belik District, Pemalang Regency

\begin{tabular}{llll}
\hline Number & Information & Sum (person) & Percentage (\%) \\
\hline 1 & age & & \\
& $15-49$ & 22 & 44,00 \\
& $50-64$ & 18 & 36,00 \\
2 & 10 & 20,00 \\
& Formal Education & & \\
& Non Educated & 15 & 30,00 \\
& Primary School & 20 & 40,00 \\
& Junior high & 9 & 18,00 \\
& Senior high & 5 & 10,00 \\
& University & 1 & 2,00 \\
& Experience (year) & & \\
& $\leq 10$ & 22 & 44,00 \\
& $11-20$ & 24 & 48,00 \\
& $21-30$ & 3 & 2,00 \\
& $>30$ & & 6,00 \\
& Main Job & 31 & 62,00 \\
& Farmer & 1 & 2,00 \\
& Labor & 7 & 14,00 \\
& Trader & 0 & 0,00 \\
& Civil servant/army/police & 11 & 22,00 \\
& Other & & \\
& Wide land area (Ha) & 19 & 38,00 \\
& $\leq 0,25$ & 18 & 36,00 \\
& $0,26-0,5$ & 13 & 26,00 \\
\hline
\end{tabular}

BPS-Statistic of Central Java (2018) classifies the productive age as 0-14 years of nonproductive, 15-49 years of very productive, 50-64 years of productive, $\geq 65$ years of less productive. $80 \%$ of respondents are of productive age. Productive age affects the physical ability of farmers in managing their farming. According to Kurniati (2015), farmers who work in productive age will be better and more optimal than those of productive age.

Education level of the respondents consisted $40 \%$ people graduated from elementary school. In accordance with the opinion of Watemin and Utami (2019) that the formal education levels that have been taken by pineapple farmers in Belik District are $63.33 \%$ only educated up to elementary school. As Soekartawi (2002) argues, low levels of education will hinder the process of technology adoption. Thus the level of education is very influential in the absorption of knowledge or technology adoption.

The length of farming affects the level of knowledge and experience of farmers in running their farming business; there were $48 \%$ respondens have experience in pineapple farming for 11-20 years. According to Scott's opinion in Rafika (2015) stated that formal and informal education is needed to support one's ability to work, but this is not absolute because of the limited resources owned by farmers so that farmers prefer to carry out their farming activities with the lowest risk based on experience during farming.

It is very important to enrich farmers' insights in pineapple cultivation, harvest and postharvest as well as marketing strategies. This is related to the counseling provided by field extension officers to farmers. Fadwiwati et al (2014) state that farmers who have access to extension services have a better position in using available resources and making use of the knowledge received.

The land owned by farmers in Belik District is dry land which is suitable for horticultural crops. The land area owned by the respondents was $\leq 0.25$ ha as much as $38 \%, 0.26-0.5$ ha 
$36 \%,>0.5$ ha $26 \%$. With an average of $4,708 \mathrm{~m} 2$ per head of family, this means that it is less than the average smallholder farmer used as a measure by the BPS-Statistics of Central Java, namely 0.5 hectares per head of farmer family. The area of land owned by farmers in general has decreased due to the process of inheritance to the next generation and the transfer of land functions from agriculture to non-agriculture (Watemin and Utami, 2019).

The results showed that the potential for pineapple production in Belik District, Pemalang Regency was $0.51 \mathrm{~kg}$ / clump in 1 year with an average production of 13,221.45 $\mathrm{kg}$ on an average land area of $4,708 \mathrm{~m} 2$. The average harvest frequency is 1.86 times in 1 year, while based on the income analysis, the production costs, revenues, and income are obtained on a land area of $4,708 \mathrm{~m}^{2}$ per year.

Table 3 - Pineapple production costs, revenue and income per year

\begin{tabular}{lll}
\hline Component & Sum (Rp) & Percentage (\%) \\
\hline Fixed Cost & 2.989 .580 & 18,17 \\
1. land lease & 2.354 .000 & 14,31 \\
2. tax & 47.080 & 0,29 \\
3. Tools & 588.500 & 3,58 \\
Variable Cost & 13.462 .175 & 81,83 \\
1. seeds & 6.770 .000 & 41,15 \\
2. manure & 856.500 & 5,21 \\
3. chemical fertilizer & 431.375 & 2,62 \\
4. Ethrel & 41.100 & 0,25 \\
5. labor & 5.363 .200 & 32,60 \\
Total cost & 16.451 .755 & 100,00 \\
Revenue & 58.703 .238 & \\
Income & 42.044 .770 & \\
RC/Ratio & 3,57 & \\
Profitability & 64,21 & \\
\hline
\end{tabular}

$R$ / $C$ ratio has a value of 3.57 , thus it can be concluded that the business is profitable and feasible to run. Widiastuti (2013) states that if the $R$ / C ratio is more than 1 then the business is profitable. In addition, the profitability value was $64.21 \%$ in 1 year, if divided each month, the value was $5.35 \%$. This ratio shows a positive result and is greater than BRI Bank's deposit interest rate of $5,5 \%$ for a year tenor (the average bank deposit interest rate per month is $0.46 \%$ ) which means that pineapple farming is feasible to be cultivated and developed. Soekartawi (2002) states that, the higher the difference between the profitability ratio and the alternative costs, it shows a good level of management so that the farming business being cultivated is feasible to be developed.

In the One Sample T-Test different test for normally distributed data, the result of the significance value of Assymp Sig ( 2 tailed) is $0.00 \leq 0.05$, where $\mathrm{H} 0$ is rejected and $\mathrm{H} 1$ is accepted. This result is reinforced by the opinion of Ambarsari et al. (2014) if the profitability ratio generated from a farming business is higher than the bank interest rate, the farming business is feasible to develop and the higher the difference between the profitability ratio and the alternative costs, it shows a good level of business management.

Testing of production function data variables is needed to obtain the ordinary least square (OLS) estimation method which will produce an unbiased value or BLUE (Best Linear Unbiased Estimator).

Normally distributed data based on normality testing using the Kolmogorov Smirnov method, each variable shows that the dots spread around the line and follow the diagonal line so that the residual value is normal.

Results of the multicollinearity test are that there is no multicollinearity with a tolerance value for each independent variable of more than 0.1 and a VIF value of less than 10 , so it can be concluded that there is no correlation between the independent variables.

There is no heteroscedasticity which can be seen from the error distribution pattern on the scatterplot graph, there is no clear pattern, and the dots spread above and below the number 0 on the $\mathrm{Y}$ axis. 

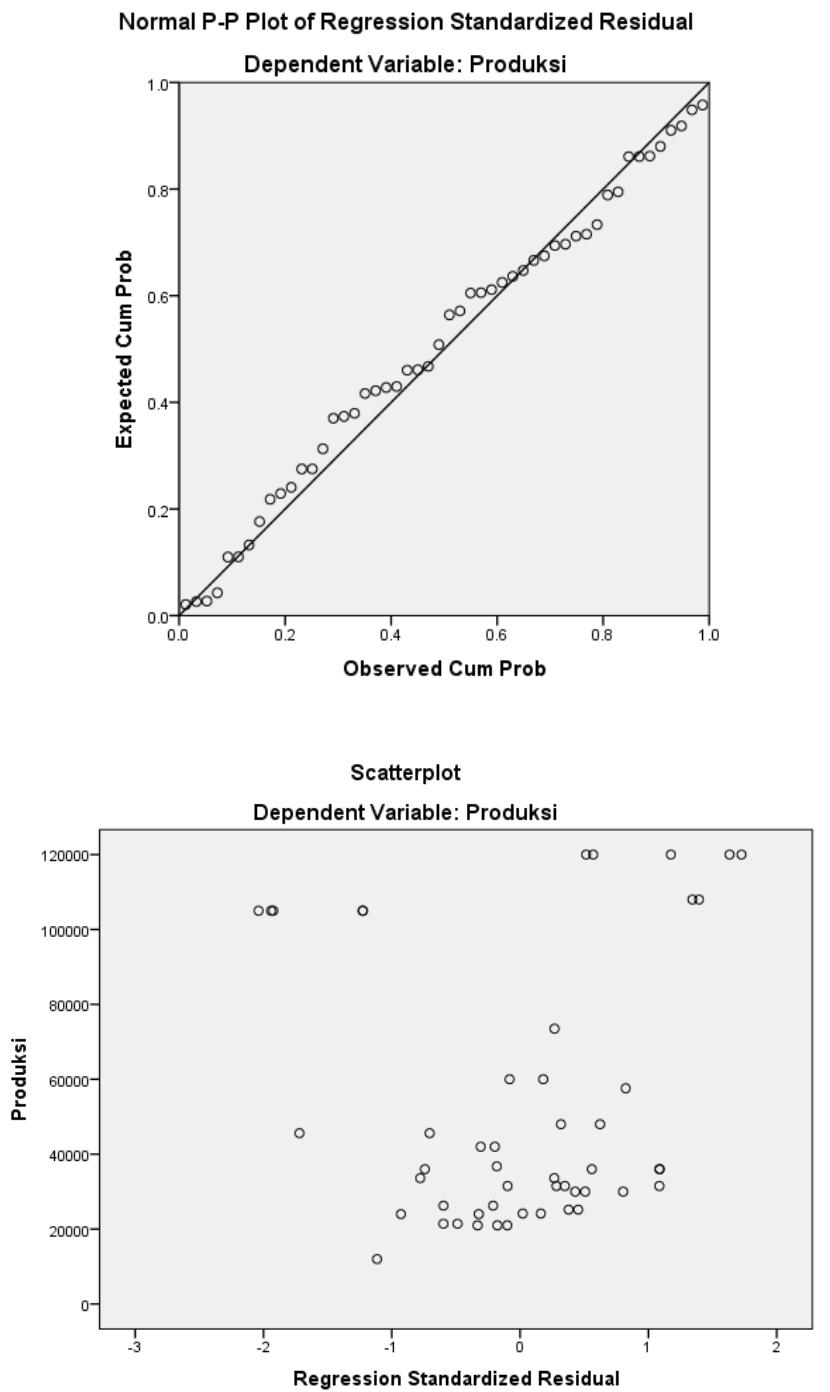

Table 4 - Multicollinearity test (Coefficients ${ }^{\mathrm{a}}$ )

\begin{tabular}{|c|c|c|c|c|c|}
\hline \multirow[t]{2}{*}{ Model } & \multicolumn{2}{|c|}{$\begin{array}{l}\text { Unstandardized } \\
\text { Coefficients }\end{array}$} & \multirow{2}{*}{$\begin{array}{l}\text { Standardized } \\
\text { Coefficients } \\
\text { Beta }\end{array}$} & $\begin{array}{l}\text { Collinearit } \\
\text { Sig. Statistics }\end{array}$ & Collinearity \\
\hline & $\mathrm{B}$ & Std. Error & & Tolerance & VIF \\
\hline (Constant) & -10299.486 & 4028.530 & & -2.557 .014 & \\
\hline Farming Experience & -34.833 & 69.356 & -.008 & $-.502 \quad 618.827$ & 1.210 \\
\hline Area $(\mathrm{m} 2)$ & 10.355 & .497 & .894 & 20.819 .000 .124 & 8.032 \\
\hline Harvesting Frequency in 1 & 5340.356 & 1670.852 & .053 & $\begin{array}{ll}3.196 & .003 .842\end{array}$ & 1.187 \\
\hline${ }^{1}$ Sum Seeds & -.258 & .088 & -.134 & -2.923 .006 .109 & 9.168 \\
\hline Sum organic fertilizer & .690 & .266 & .098 & $2.594 \quad 013.160$ & 6.247 \\
\hline Sum chemical fertilizer & -2.428 & 6.292 & -.011 & $\begin{array}{ll}-.386 & .702 .263\end{array}$ & 3.800 \\
\hline Sum of Ethrel & 151.662 & 924.585 & .003 & . 1641.766 & 1.306 \\
\hline Sum of labor & 27.983 & 9.122 & .145 & 3.068 .004 .102 & 9.784 \\
\hline
\end{tabular}

a. Dependent Variable: Production.

Table 5 - Uji Autokorelasi (Model Summary ${ }^{\mathrm{b}}$ )

\begin{tabular}{|c|c|c|c|c|}
\hline Model & $\mathrm{R}$ & R Square & Adjusted R Square & Std. Error of the Estimate Durbin-Watson \\
\hline 1 & $.995^{\mathrm{a}}$ & .991 & .989 & $\begin{array}{ll}3762.457 & 1.438 \\
\end{array}$ \\
\hline
\end{tabular}

a. Predictors: (Constant), Amount of Labor, Farming Experience, Frequency of harvest in 1 year, Amount of Ethrel, Amount of Manure, Amount of Chemical Fertilizer, Area of Land (m2), Number of Seeds.

b. Dependent Variable: Production. 
Results of the autocorrelation test did not find any correlation between confounding errors in period t with period $t-1$ or before it can be seen in the Durbin Watson (DW) number obtained by 1.438 not above +2 or below -2 (Santosa, 2001).

Multiple linear regression analysis can be used to prove the hypothesis because the test results have met the assumptions of normality, multicollinearity, heteroscedasticity and autocorrelation. The resulting Cobb Douglas Production Function equation model is as follows:

$\operatorname{LnY}=4,592+0,895 \ln X_{1}+0,136 \ln X_{2}+(-0,159) \ln X_{3}+(-0,007) \ln X_{4}+0,344 \ln X_{5}+0,24 \ln X_{6}+(-0,07) \ln X_{7}+0,295 \ln X_{7}$

Table 6 - Uji F (ANOVA $\left.{ }^{a}\right)$

\begin{tabular}{lllllll}
\hline Model & & Sum of Squares & $\mathrm{df}$ & Mean Square & $\mathrm{F}$ & Sig. \\
\hline \multirow{2}{*}{1} & Regression & 61054703899.229 & 8 & 7631837987.404 & 539.121 & $.000^{\mathrm{D}}$ \\
& Residual & 580399318.771 & 41 & 14156080.946 & & \\
& Total & 61635103218.000 & 49 & & & \\
\hline
\end{tabular}

a. Dependent Variable: Production.

b. Predictors: Constant), Amount of Labor, Experience of farming, Frequency of harvest in 1 year, Amount of Ethrel, Amount of Manure, Amount of Chemical Fertilizer, Area of Land $\left(m^{2}\right)$, Number of Seeds.

Based on multiple regression analysis, the results of the $\mathrm{F}$ test using SPSS 20 show a significance value of $0.000<0.05$, it means that the variables of land area, labor, seeds, ethrel, manure, chemical fertilizers, farming experience and harvest frequency in 1 year simultaneously has a significant effect on pineapple production.

The $T$ test was conducted to determine the effect of the independent variables partially on the dependent variable. If the t test is done by comparing each $t$ count with the table. Variables that have $t$ count greater than t table have a significant effect on the amount of pineapple production.

In the multiple linear equation above, it can be explained that $\mathrm{a}=4.592$ is a constant which means that without the variables of land area, labor, number of seeds, amount of ethrel manure, chemical fertilizers, length of farming and frequency of harvest in 1 year will increase production pineapples of $4.592 \mathrm{~kg}$ on an average land area of $4708 \mathrm{~m}^{2}$.

The coefficient of land area (b1) $=0.895$, with a significant value of $0.000<\mathrm{P}$, then $\mathrm{H} 0$ is rejected and $\mathrm{H} 1$ is accepted. Thus, land area has a significant effect on pineapple production. A positive $t$ value indicates that the land area has a direct relationship with production. For each additional land area of 1 unit, the production value will increase by $0.895 \%$. If the average land area is $4708 \mathrm{~m} 2$, it will increase the production of $42,14 \mathrm{~kg}$. Arifin (2020) states that, the increasing land area will increase the number of plants per land area so that it can increase the amount of production.

The labor coefficient $(\mathrm{b} 2)=0.136$ with a significant value of $0.028<\mathrm{P}$ then $\mathrm{H} 0$ is rejected and $\mathrm{H} 1$ is accepted. Thus the variable number of workers has a significant effect on the amount of pineapple production. The coefficient value of 0.136 means, each additional workforce of $1 \%$ from the average will increase production by $0.136 \%$. If the average use of labor is $268.16 \mathrm{HOK}$, it will increase production by $0.36 \mathrm{~kg}$. According to Mulyana et al (2017), the average use of labor in pineapple production in a year is $393.52 \mathrm{HKP}$. And the activity that requires the longest time is land processing of $160.29 \mathrm{HKP}$.

The coefficient of the number of seeds (b3) $=-0.159$, with a significant value of 0.011 $<\mathrm{P}$, then $\mathrm{HO}$ is rejected and $\mathrm{H} 1$ is accepted. Thus the variable number of seeds has a significant effect on the amount of pineapple production. The coefficient value -0.159 means that each additional number of seeds of $1 \%$ of the average will reduce the production of $0.159 \%$. If the average use of seedlings is 27,080 stems on a land area of $4708 \mathrm{~m} 2$, it will reduce the production to $43.06 \mathrm{~kg}$. According to the Purbalingga Regency Agriculture, Plantation and Forestry Service (2018), the ideal number of pineapple seedlings is a maximum of 60,000 stems / ha, but the number of pineapple seeds planted still has to adjust to soil conditions. 
The coefficient of ethrel / fruit stimulant $(b 4)=-0.007$, with a significant value of $0.886>$ $\mathrm{P}$ then $\mathrm{HO}$ is accepted and $\mathrm{H} 1$ is rejected. Thus the ethrel variable has no significant effect on the amount of pineapple production. The coefficient value of -0.007 means, each additional amount of ethrel by $1 \%$ of the average will reduce the production of $0.007 \%$. The results didn't give significant effect, but based on research by Puspitorini et al (2018) which stated that giving ethrel had a significant effect on flowering and could increase flower diameter and flower uniformity. This is in line with information from respondents in the study area, ethrel is used to stimulate flowering.

Manure coefficient (b5) $=0.344$ with a significant value of $0.074<\mathrm{P}$ then $\mathrm{HO}$ is accepted and $\mathrm{H} 1$ is rejected. Thus manure variable has no significant effect on the amount of pineapple production. The coefficient value of 0.344 means, each additional amount of manure by $1 \%$ of the average will increase the production of $0.344 \%$. If the average use of manure is $6813.60 \mathrm{~kg}$ on a land area of $4708 \mathrm{~m}^{2}$, it will increase the production of $23,44 \mathrm{~kg}$. Hartatik et al (2015) stated that the use of organic fertilizers increases the quality of plant growth, so that the resulting production will increase.

The coefficient of chemical fertilizers $(\mathrm{b} 6)=0.24$ with a significant value of $0.707>P$, then $\mathrm{HO}$ is accepted and $\mathrm{H} 1$ is rejected. Thus the chemical fertilizer variable has no significant effect on the amount of pineapple production. The coefficient value of 0.24 means, each additional amount of chemical fertilizers by $1 \%$ from the average will increase the production of $0.24 \%$. If the average use of chemical fertilizers (Phonska) is $246.50 \mathrm{~kg}$ on an area of $4708 \mathrm{~m} 2$, it will increase the production of $0.59 \mathrm{~kg}$. Based on information from the Pemalang Regency Agriculture and Forestry Service (2013), it is stated that in order to determine the correct fertilizer dose, a complete soil analysis must be carried out. Obiefuna et al (1987) stated that nitrogen fertilizer (N) $200 \mathrm{~kg} / \mathrm{ha} /$ year and phosphorus (P) $50 \mathrm{~kg} /$ ha or potassium (K) $200 \mathrm{~kg} / \mathrm{ha} /$ year significantly increased pineapple production. The composition result of NPK 200-50-200 shows the highest quality pineapple production.

The coefficient of farming experience $(b 7)=-0.007$ with a significant value of $0.812>$ $\mathrm{P}$ then $\mathrm{H} 0$ is accepted and $\mathrm{H} 1$ is rejected. Thus the farming experience variable does not have a significant effect on the amount of pineapple production. The coefficient value of 0.007 means, each additional farming experience by $1 \%$ of the average will reduce production by $0.007 \%$. If the average farming experience is 15.86 years on an area of 4708 $\mathrm{m} 2$, it will reduce the production of $0.001 \mathrm{~kg}$. Based on respondents' information, the ability of pineapple cultivation in the study area initially used traditional methods, especially pineapple farmers who have long been reluctant to adopt technology. Meanwhile, pineapple farmers have now adopted technology and are actively seeking information to increase pineapple production. Fadwiwati et al. (2014) stated that farmers who have access to extension services have a better position in using available resources and making use of the knowledge received.

Harvest frequency coefficient $(\mathrm{b} 8)=0.295$ with a significant value $0.000<\mathrm{P}$ then $\mathrm{H} 0$ is rejected and $\mathrm{H} 1$ is accepted. Thus, the variable of harvest frequency in 1 year has significant effect on the amount of pineapple production. The coefficient value of 0.295 means that each additional harvest frequency of $1 \%$ in 1 year from the average will increase production by $0.295 \%$. If the average harvest frequency in 1 year is 1.86 on a land area of $4708 \mathrm{~m} 2$, it will increase the production by $0.005 \mathrm{~kg}$. Based on respondents' information, the harvest frequency regulation aims to maintain product continuity in the market.

The competitiveness analysis used is the Policy Analysis Matrix (PAM) and the calculation results are as follows:

Table 7 - Policy Analysis Matrix (PAM)

\begin{tabular}{llllll}
\hline \multirow{2}{*}{ NO } & \multirow{2}{*}{ Items } & \multirow{2}{*}{ Revenue (Output) } & Cost & \\
\cline { 3 - 4 } & & & Input Tradeable & Input Nontreadable & Profit \\
\hline 1 & Private cost & $58,703,238$. & 353,428 & $15,390,780$ & $42,959,031$ \\
2 & Social cost & $105,771,600$ & 682,888 & $15,390,780$ & $89,697,933$ \\
3 & Policy impact & $(-47,068,362)$ & $(-329,460)$ & 0 & $(-46,738,902)$ \\
\hline
\end{tabular}


It can be seen that the farm income calculated using private cost is Rp.42,959,031.per year and the farm income calculated using social cost is Rp. 89,697,933.- per year with an average land are of $4,708 \mathrm{~m}^{2}$. In Contras the negative policy impact on revenues, tradable inputs and profits in pineapple agribusiness. This happens because the social price of pineapple is higher than the private price. Fadli et al (2007) stated that this negative policy impact condition was caused by policy distortion and market failure. Farmers are forced to sell their corps to middlemen/ village traders or collectors. Based on information from respondents, pineapple farmers experience marking difficulties, especially in main harvest, sometimes they are forced to sell by slash with a much lower profit rate when compared to selling seeds or per kilogram. Farmer really expects government policies that can help marketing problems.

Table 8 - Private Cost Ratio (PCR) and Domestik Resources Cost Ratio (DRCR)

\begin{tabular}{lll}
\hline No & Criteria & Score \\
\hline 1 & Private Cost Ratio (PCR) & 0.26 \\
2 & Domestik Resources Cost Ratio (DRCR) & 0.15 \\
\hline
\end{tabular}

It is known that the PCR (Private Cost Ratio) value is 0.26 . PCR values that are less than 1 indicate that pineapple farming in Pemalang Regency has a competitive advantage or competitiveness under existing government policies. This is in accordance with the opinion of Firdaus (2007) which states that the decision making criterion for PCR is a PCR value $<1$, so there is a competitive advantage so that it is able to compete because it has compatibility with domestic land and resources.

The DRCR value of $0.15<1$ shows that pineapple farming in Pemalang Regency has a comparative advantage. Fadli (2017) argues that the DRCR value $<1$ indicates that the pineapple agribusiness has a relatively high level of efficiency in using scarce economic resources, namely suitable cultivation areas and labor, so that it deserves to be developed to be more profitable. In order to develop pineapple agribusiness in Pemalang Regency, the government has issued a Regent Regulation Number 48 of 2018 concerning the Development Plan for Rural Areas of Pineapple Agribusiness Centers in Belik District, Pemalang Regency in 2019-2023, in order to support this design it is very important to conduct income analysis research / pineapple agribusiness profit level, analysis of production factors so that Pemalang pineapple products have high competitiveness (JDIH Regional Secretariat of Pemalang Regency, 2018).

Based on the analysis, it can be seen that the impact of government policies on pineapple agribusiness in Pemalang Regency is as follows:

Table 9 - Government Policy on Pineapple Farming

\begin{tabular}{lll}
\hline No & Criteria & Score \\
\hline 1 & Transfer Output (OT) & $(-47,068,362)$ \\
2 & TradableTransfer Input (IT) & $(-329,460)$ \\
3 & Transfer Input NonTradable (FT) & 0 \\
4 & Net Transfer (NPT) & $(-46,738,902)$ \\
5 & Nominal Protection Coefficient Output (NPCO) & 0.56 \\
6 & Nominal Protection Coefficientl nput (NPCI) & 0.52 \\
7 & Effective Protection Coefficient (EPC) & 0.56 \\
8 & Profit Coefficient (PC) & 0.48 \\
9 & Subsidy Ratio Producers (SRP) & $(-0.44)$ \\
\hline
\end{tabular}

Government policy on output is explained by output transfer (OT) and nominal protection coefficient on output (NPCO). It is known that the value of OT $(-47,068,362)$ means that government policy or intervention benefits consumers. Thus there is a shift in the surplus from farmers to consumers so that the market distortion that occurs causes private prices to be lower than the social prices (Fadli et al., 2017). The NPCO value of 0.56 indicates that pineapple farmers get the private price $56 \%$ of the social price. The NPCO 
value $<1$ indicates that there are no policies that protect domestic output or disincentive policies.

Government policy towards input is explained by the value of input transfer, nominal protection coefficient on input and transfer factor. IT value $(-329,460)$ <indicates no transfer from producer farmers to tradable input producers. The NPCl value $0.52<1$ indicates the level of government protection against domestic agricultural input prices. This shows that there is a policy of subsidies for tradable inputs, in which farmers buy tradable inputs $52 \%$ cheaper than the price of their social inputs. Based on respondent information that currently pineapple farmers in Pemalang Regency use subsidized chemical fertilizers in accordance with the Implementation Guidelines for the Definitive Needs Group Plan (RDKK) for subsidized fertilizers as a follow-up to The Regulation of The ministry of Agriculture No. 82/Permentan/OT.140/8/2013 concerning Fostering of Farmer Groups and Association of Farmer Groups (Directorate of Fertilizers and Pesticides, 2014).

EPC is an indicator that shows a simultaneous level of protection against tradable output and input. The EPC value in pineapple agribusiness in Pemalang Regency is 0.56 < indicating that there is no positive impact of government policies in price formation and commodity market mechanisms have not provided incentives (protection) to pineapple farmers in Pemalang Regency.

NPT is the difference between the net profit actually received by the producer and the social net profit. The NPT value $(-46,738,902)<0$ indicates that there is no additional producer surplus caused by government policies applied to inputs and outputs. Although there are government policies related to tradable inputs (chemical fertilizers), the absence of government policies on output prices causes the actual pineapple prices at the farmer level to be lower than the social prices for pineapples in the market.

$\mathrm{PC}$ is the profit coefficient which is the ratio between the net profit actually received by producers and the net social profit. The PC value $0.48<1$ indicates that overall government policies have not provided incentives to producers. Social benefits are higher than private profits.

The SRP is an indicator that shows the proportion of revenue at the social price required if subsidies or taxes are used as a substitute for government policies. The SRP value of -0.44 indicates no positive impact from government policies, which means that farmers have to pay higher prices to produce than the added value of the benefits they receive. Even though the government has made a policy on subsidized fertilizers, because social prices are much higher than private prices, the impact of government policies is not visible on the subsidy ratio.

\section{CONCLUSION}

Based on the results of the analysis and discussion, it can be concluded as follows:

1. Pineapple farm in Pemalang regency had mediate production amounted to $0,51 \mathrm{~kg} /$ clump/year. It was equal production of $13.221,45 \mathrm{~kg} / 4.708 \mathrm{~m}^{2}$ with $\mathrm{R} / \mathrm{C}$ ratio of 3.41 and probability value of $5,40 \%$ /month. The result was higher than interest rates of $0,46 \% /$ month. It can be said than pineapple farm in Pemalang regency was feasible;

2. The production factors (namely: farm size, number of farm labour, seed, ethrel, fertilizer, chemical fertilizer, experience in farming system dan harvesting period) had significant effect toward pineapple farm simultaneously in a year. Moreover, in farm size, number of farm labour and harvesting period had significant effect toward pineapple farm. In addition, fertilizer and chemical fertilizer, ethrel and experience in farming system had not significantly effect toward pineapple farm;

3. Pineapple farm had strong competitive ability as indicated by PCR and DRCR value of 0.26 and 0.15 respectively. $\mathrm{NPCl}$ value of 0.52 shows that it had impact on farmer' tradability. NPCO value of 0.56 show that there was lack of impact on government policy toward farmer' output. Moreover, government policy of input and output on 
pineapple farm had not been achieved positive effect toward income of pineapple farmers in Pemalang Regency.

Government policy towards increasing the competitiveness of pineapple farmers in Pemalang Regency emphasizes aspects related to increasing output prices at the farmer level, increasing productivity, increasing quality and increasing the role of institutions in increasing added value. Furthermore, post-harvest handling technology regarding the preservation of fresh products so that when the export of fresh pineapple fruit requires a long delivery time the fruit can be durable and not rot on the way.

\section{REFERENCES}

1. Ambarsari, W., Yunianto, VD., Ismail, B., and Setiadi, A., 2014. Analysis of Income and Profitability of Rice Farming (Oryza sativa, L.) in Indramayu Regency. Journal of Agri Wiralodra. 6 (2) pp 19-27.

2. Arifin, Z. 2020. Technical And Economic Efficiency In Use of Production Factors at Cabbage Farming in Getasan District of Semarang Regency. Thesis. Master of Agribusiness, Faculty of Animal and Agricultural Sciences, Diponegoro University

3. Astoko E. 2014. Pineapple (Ananas comssus L. Merr) Agribusiness Development Strategy in Kediri Regency, East Java Province. Jurnal Manajemen Agribisnis Vol 14 (2) p17.

4. BPS-Statistics Indonesia. 2018. Production of Fruits 2018. BPS-Statistics Indonesia. Jakarta.

5. BPS-Statistics of Central Java. 2018. Jawa Tengah Province in Figure 2018. BPSStatistics of Central Java. Semarang.

6. Purbalingga Regency Agriculture, Plantation and Forestry Service. 2018. Honey Pineapple Cultivation. dinpertan.purbalinggakab.go.id

7. Directorate General of Horticulture. 2017. Performance Report of the Directorate General of Horticulture, Ministry of Agriculture for Fiscal Year 2017. Ministry of Agriculture. Jakarta.

8. Pemalang Regency Agriculture and Forestry Service. 2013. Standard Operating Procedure (SOP) for Pineapple Pemalang, Pemalang Regency. Pemalang Regency Agriculture and Forestry Service. Pemalang.

9. Pemalang Regency Agriculture and Forestry Service. 2017. Area of Harvest and Production of Fruits by District in Pemalang Regency. Pemalang Regency Agriculture and Forestry Service. Pemalang

10. Directorate of Fertilizers and Pesticides. 2014. Guidelines for Developing a Definitive Plan for Farmer Group Needs (RDKK) for Subsidized Fertilizer. Directorate of Fertilizers and Pesticides, Directorate General of Agricultural Infrastructure and Facilities, Ministry of Agriculture. Jakarta.

11. Fadli, R. Pambudy, and Harianto. 2017. Analysis of the Competitiveness of Seaweed Agribusiness in East Lombok Regency. Jurnal of Indonesia Agribusiness Vol 5(2) pp 89102.

12. Fidwiwati, A. S. Hartoyo. Kuncoro and W. Rusastra. 2014. Analysis of technical, allocative, and economic efficiency of corn farming based on varieties in Gorontalo Province. Jurnal Agro Ekonomi 32 (1) pp 1 - 12

13. Firdaus, M. 2007. Competitiveness Analysis Soybean East Java. Jurnal SEP 1 (2) pp 1627

14. Ghozali, I. 2011. Multivariate Analysis Application with SPSS Program. Diponegoro University Publishing Agency, Semarang.

15. Hartatik, W., Husnain, and L. Widowati. 2015. Cabbage Farm Technical Efficiency Analysis in Agam West Sumatra. Jurnal Hexagro Vol 2 (1) pp 22-29

16. JDIH Setda Pemalang Regency. 2018. a Regent Regulation Number 48 of 2018 concerning the Development Plan for Rural Areas of Pineapple Agribusiness Centers in Belik District, Pemalang Regency in 2019-2023. jdih.pemalangkab.go.id 
17. Kurniati, D. 2015. Farmer Behavior Against the Risks of Soybean Farming in South Jawai District, Sambas Regency. Jurnal Social Economic of Agriculture 4 (1) pp 32-36

18. Maulidah, S. 2012. Introduction to Agribusiness Management. UB Press, Malang.

19. Mulyana, E., E. Purbiyanti, I. Januarti. 2017. Level Of Optimization Of Pineapple Farmer's Workers In Tanjung Atap Village, Tanjung Batu Subdistrict Ogan Ilir District. Proceedings of the 2017 National Seminar, Faculty of Agriculture, UMJ, Sustainable Agriculture and Herbal Plants in Indonesia pp 278- 283

20. Novitasari D. 2015. The sweetness of the profit from Pemalang Honey Pineapple. [cited 2019: 13 Januari 2019]; Available from: https://www.elshinta.com/news/12655/2015/05/22/manisnya-laba-dari-nanas-madupemalang-tertarik. Jakarta.

21. Obiefuna, J,C., P.K. Majumder dan A.C. Ucheagwu. 1987. Fertilizer Rates For Increased Pineapple Production In The Tropical Ferrallitic Soils Of South Western Nigeria. Fertilizer research volume 12, pp 99-105.

22. Pasaribu A. 2012. Agribusiness Project Planning and Evaluation: CV Andi. Yogyakarta.

23. Puspitorini, P. and T. Kurniastuti. 2018. The Effect of Several Doses of Ethylene on Flowering of Pineapple (Ananas comussus L,) Queen Varieties. Jurnal Viabel Pertanian Vol. 12 (2) pp 11-19.

24. Rafika, I. 2015. Analysis of Clove Household Income in Salumpaga Village, North Tolitoli District, Tolitoli Regency. Jurnal Katalogis 3 (8) pp 38-46.

25. Santoso, S. 2001. Parametric Analysis with SPSS. PT. Elex Media Komputindo, Jakarta.

26. Santoso, S. 2010. Multivariate Statistics. PT. Elex Media Komputindo, Jakarta.

27. Soekartawi. 1993. Basic Principles of Agricultural Economics, Theory and Application. Rev Edition. PT. Raja Grafindo Persada.Jakarta.

28. Soekartawi. 2002. Farming Analysis. UI Press, Jakarta.

29. Soekartawi. 2003. The Economic Theory of Production with the Subject of CobbDouglass Function Analysis. PT. Rajagrafindo Persada.Jakarta.

30. Suratiyah, K. 2015. Agricultural Science (Revised Edition). Penebar Swadaya, Jakarta.

31. Suryani dan Hendryadi. 2015. Quantitative Research Methods: Theory and Application in Research in Management and Islamic Economics. Prenadamedia Group, Jakarta.

32. Watemin dan P. Utami. 2019. The Entrepreneurship Level of Pineapple Farmers Identification in Belik District Pemalang Regency. Seminar Nasional Hasil Penelitian dan Pengabdian Pada Masyarakat IV pp 640-649.

33. Widiastuti N. 2013. Corn Marketing Channels and Margins in Grobogan Regency. Jurnal SEPA. Vol 9 (2) pp 231-240. 